\title{
BRITISH MUSEUM NATURAL RADIOCARBON MEASUREMENTS XX
}

\author{
JANET AMBERS, KEITH MATTHEWS, and SHERIDAN BOWMAN \\ Research Laboratory, The British Museum, London WC1 B 3DG, England
}

The following list consists of dates, obtained by liquid scintillation counting of benzene, for archaeologic samples mostly measured from June 1985 to June 1986.

Charcoal and grain samples were pretreated with $1 \mathrm{M} \mathrm{HCl}$ followed by washing in water and, where considered necessary, with dilute alkali for the removal of humic acids. Wood samples were treated either in the same way, or, where large enough, were reduced to cellulose by the action of chlorine dioxide produced in situ. All antler and bone samples were treated with cold dilute acid. The term 'collagen' is used throughout to mean the acid insoluble organic fraction produced by this treatment. Peat samples were treated with dilute acid and alkali to separate the humin and humic acid fractions, which were dated separately.

The dates were obtained by liquid scintillation counting of benzene in low potassium glass vials, specially selected for similar backgrounds (Ambers, Leese \& Bowman, 1986) in a Packard model 3255 scintillation counter, using PPO in toluene as a scintillator. The maximum sample size used was $5.5 \mathrm{ml}$ and smaller samples were made up to this volume with 'dead' benzene. Samples were counted for a minimum total period of $2000 \mathrm{~min}$ utes in trains containing at least 2 background and 2 modern samples. Each sample in the train was counted in successive 50-minute periods to achieve quasi-simultaneous counting. This procedure is basically the same as outlined in previous lists (see, eg, BM VIII, R, 1976, v 18, p 16).

Dates are expressed as suggested by Stuiver and Polach (1977), $i e$, in radiocarbon years relative to $\mathrm{AD} 1950$, based on the Libby half-life for ${ }^{14} \mathrm{C}$ of $5570 \mathrm{yr}$, and corrected for isotopic fractionation $\left(\delta^{13} \mathrm{C}\right.$ values are given relative to $\mathrm{PDB})$. The 1986 recommendations on the expression of calibrated and uncalibrated dates (, 1986 , v 28, no. 2A, p 799) have been followed. The modern reference standards are the NBS oxalic acids (SRM 4990 and RM 49).

Errors quoted are the counting error for the sample combined with an estimate of the errors contributed by the modern and background samples. This estimate includes both counting and non-counting errors, the latter being computed from differences in the overall count-rates observed among the individual backgrounds and moderns. The overall error is given as \pm 1 standard deviation $( \pm 1 \sigma)$.

Descriptions, comments, and references to publications are based on information supplied by submitters. 
Algeria

\section{Sétif series}

Samples from Islamic occupation of Roman city of Sétif, W of Constantine $\left(36^{\circ} 10^{\prime} \mathrm{N}, 5^{\circ} 20^{\prime} \mathrm{E}\right)$. Coll 1982 and subm by T W Potter, Dept Prehist and Romano-British Antiquities, British Mus, for Elizabeth Fentress.

\section{BM-2368. Sétif}

$1230 \pm 150$

Charcoal, ref Th404, from layer representing destruction of Islamic structure.

\section{BM-2369. Sétif}

$\mathbf{1 1 7 0} \pm \mathbf{5 0}$
$\delta^{13} \mathrm{C}=-22.0^{\circ} \% 0$

Charcoal, ref Th339, from fill of deep pit, probably intended for grain storage.

General Comment (EF): BM-2368 derives from burning of Medieval house, assoc with apparently 9 th century AD pottery. BM-2369, from fill of collective grain pit, confirms view that this is part of first Islamic activity on site.

\section{British Isles}

England

\section{Chelm's Combe Shelter series}

Collagen from bone samples from Chelm's Combe rock shelter (Balch, 1927), Cheddar, Somerset ( $51^{\circ} 15^{\prime} \mathrm{N}, 2^{\circ} 50^{\prime} \mathrm{W}$, Natl Grid Ref ST 463545). Coll 1925 to 1926 by H E Balch for Somerset Archaeol Soc and subm 1985 by R M Jacobi, Univ Lancaster from colln of Wells Mus, as addition to series of dates for remains of reindeer in British Isles (see, eg, R, 1985, v 25, p 517) and as part of investigation of chronology of late glacial faunas of Cheddar area.

\section{BM-2318. Chelm's Combe Shelter}

$$
\begin{array}{r}
10,190 \pm 130 \\
\delta^{13} C=-18.7 \% 0
\end{array}
$$

Collagen from long bone (metapodial of Rangifer tarandus) id. by A P Currant and Juliet Clutton-Brock, British Mus (Nat Hist), from Spit 12 of excavation $\mathrm{A}$ in angluar limestone scree below rock-face.

\section{BM-2431. Chelm's Combe Shelter}

$$
10,220 \pm 130
$$

$\delta^{13} \mathrm{C}=-18.9 \%$

Collagen from long bone (right distal tibia of Rangifer tarandus) id. by A P Currant and Juliet Clutton-Brock, from Spit 7 of excavation A in angular limestone scree below rock-face.

General Comment (RJ): results provide first age estimates for one sp within rich mammal, small-mammal, and bird fauna which is presently being studied by A P Currant and C J O Harrison (British Mus (Nat Hist)). Contemporary human activity at site has still to be demonstrated. 


\section{Turnford series}

Samples from Bronze Age site at Halfhide Lane, Turnford, W side of Lea Valley, Hertfordshire $\left(51^{\circ} 40^{\prime} \mathrm{N}, 0^{\circ} 00^{\prime}\right.$ E, Natl Grid Ref TL 363043). Coll 1983 and subm by D S Stewart, Herts Archaeol Unit.

\section{BM-2331. Turnford}

$2650 \pm 90$

Charcoal, ref U40.011, (Quercus sp) id. by Janet Ambers, from fill of pit assoc with large group of pottery.

\section{BM-2333. Turnford}

$3320 \pm 180$

Charcoal, ref U72.010, from fill of shallow depression, close to possible ovens or metalworking hearths.

General Comment (DS): BM-2331 was assoc with post Deverel-Rimbury pottery and from strat was expected to date between 10 th and 8 th centuries BC. BM-2331 thus confirms dating based on pottery. Feature from which BM2333 was taken is strat earlier than possible ovens or hearths; sample may be connected with scrub clearance or other activity on site.

\section{BM-2339. Canewdon}

$$
\begin{array}{r}
\mathbf{2 9 0 0} \pm \mathbf{7 0} \\
\delta^{13} C=-27.7 \% 0
\end{array}
$$

Wood, ref AS A7470, from broken ends of oar (estimated 17 growth rings across) found in Holocene estuarine clay deposit at Canewdon, Essex $\left(51^{\circ} 37^{\prime} \mathrm{N}, 0^{\circ} 45^{\prime} \mathrm{E}\right.$, Natl Grid Ref TQ 924959). Coll 1983 and subm by T J Wilkinson, Archaeol Section, Essex Co Council to establish date for unique object with no assoc material. Comment by S V E Heal, Archaeol Research Centre, Natl Maritime Mus, Greenwich. Comment (SVEH): dates form of paddle and implied use of water transport on R Crouch. Found at contemporary high water mark, it also dates fixed point in study of tidal regime of area (Wilkinson, 1983).

\section{BM-2346. Giants' Hills 2, Skendleby}

$$
\begin{array}{r}
4120 \pm 45 \\
\delta^{l 3} C=-23.6 \% 0
\end{array}
$$

Collagen from distal end and shaft of tibia of Bos primigenius (sample ref 355), id. by J G Evans, Dept Archaeol, Univ College, Cardiff, from Layer 4 in Cutting MN, late Neolithic horizon in ditch on $\mathrm{S}$ side Giants' Hills 2 Long Barrow, Skendleby, Lincolnshire $\left(53^{\circ} 15^{\prime} \mathrm{N}, 0^{\circ} 10^{\prime} \mathrm{E}\right.$, Natl Grid Ref TF 429709). Coll 1976 and subm 1985 by J G Evans to provide date for Layer 4, and as part of post-Pleistocene mammalian extinctions program (R, 1983, v 25, p 39-41); charcoal, human bone, and red deer antler from other contexts at Giants' Hills 2 are being dated at Cardiff, Oxford, and Harwell labs. Comment (JGE): BM-2346 is late in series of ${ }^{14} \mathrm{C}$ dates for Neolithic activity on site which spans $5450 \pm 80 \mathrm{BP}(\mathrm{OxA}-641)$ to $3830 \pm 60 \mathrm{BP}(\mathrm{CAR}-816)$ and derives from period of late Neolithic re-use of site represented by CAR-818, 4450 $\pm 70 \mathrm{BP}, \mathrm{CAR}-817,4370 \pm 70 \mathrm{BP}$ and 
CAR-816, $3830 \pm 60$ BP (Evans \& Simpson, 1986). BM-2346 overlaps at $2 \sigma$ with dates from red deer antlers from Giants' Hills 1 Long Barrow, BM$192,4320 \pm 150 \mathrm{BP}$ and $\mathrm{BM}-191,4410 \pm 150 \mathrm{BP}(\mathrm{R}, 1969, \mathrm{v} 11, \mathrm{p} 278-$ 284).

\section{BM-2350. Seamer Carr}

$$
\begin{array}{r}
\mathbf{9 7 9 0} \pm \mathbf{1 8 0} \\
\delta^{13} C=-24.1 \% \text { o }
\end{array}
$$

Collagen from fragmentary right mandibular ramus of wild horse, Equus ferus, id. by Juliet Clutton-Brock, British Mus (Nat Hist), from Mesolithic site preserved in peat deposits at Seamer Carr, $4.8 \mathrm{~km} \mathrm{~W}$ of Scarborough, Vale of Pickering, N Yorkshire $\left(54^{\circ} 15^{\prime} \mathrm{N}, 0^{\circ} 30^{\prime} \mathrm{W}\right.$, Natl Grid Ref TA 030835). Coll 1984 by T Schadla-Hall and subm by J Clutton-Brock as part of British late Pleistocene/early Holocene extinctions program (see, eg, R, 1983, v 25, p 39-41). Comment supplied by J Clutton-Brock and R Burleigh. Comment (JC-B \& RB): remains of wild horse from Seamer Carr were assumed to be Late Glacial, but this late date confirms that horse survived into Boreal period and was component of Seamer Carr and contemporaneous nearby Star Carr mammal fauna $(c f Q-14,9557 \pm 210 \mathrm{BP} ; \mathrm{R}, 1959$, v $1, \mathrm{p} 69)$. At present there are only two other comparable late dates for remains of horse in Britain: OxA-111, 10,000 \pm 200 BP (Gillespie et al, 1985; Burleigh et al, in press), accelerator date for decorated mandible from Kendrick's Cave, N Wales, and BM-1619, $9770 \pm 80 \mathrm{BP}(\mathrm{R}, 1982$, v 24, p 262) for metapodial from Darent gravels, Sevenoaks, Kent (CluttonBrock \& Burleigh, 1981; Harrison, Clutton-Brock \& Burleigh, 1981). After this period horse was absent or very rare in Britain until reintroduced as domestic animal in late Neolithic, ca 4000 BP (Clutton-Brock \& Burleigh, 1986 ; in press).

\section{BM-2355. Thickthorn Down}

$5160 \pm 45$

Collagen from antler, ref sample 3, (red deer) id. by J W Jackson, from group of bone and antler found together on surface of buried soil beneath N quadrant of long barrow (Drew \& Piggott, 1936) at Thickthorn Down, Gussage St Michael, Dorset $\left(50^{\circ} 55^{\prime} \mathrm{N}, 2^{\circ} 00^{\prime} \mathrm{W}\right.$, Natl Grid Ref ST 971123$)$. Coll 1933 and subm 1983 by R Bradley, Univ Reading for Dorset Co Mus. Sample had been treated with PVA and was cleaned with acetone but there is slight possibility of some contamination surviving pretreatment. Comment (RB): sample should provide terminus post quem for long barrow aligned on $\mathrm{S}$ terminal of Dorset Cursus. Date seems anomalously early compared with those for long barrows of similar form, and some contamination is likely.

\section{Grime's Graves series}

Samples from area around Canon Greenwell's pit, 19th century excavation of one of shafts in large late Neolithic flint mining complex at Grime's Graves, Weeting, Norfolk $\left(52^{\circ} 30^{\prime} \mathrm{N}, 0^{\circ} 40^{\prime} \mathrm{E}\right.$, Natl Grid Ref TL 816898). Coll 1984 during small-scale excavation for Historic Bldgs and Monuments Comm (England), following re-excavation by British Mus in 1972 to 1976, and subm by Frances Healy, Norfolk Archaeol Unit. Results 
for material from 1972 to 1976 excavation and further details are given in BM X (R, 1979, v 21, p 41-47).

\section{BM-2377. Grime's Graves}

$$
\begin{array}{r}
4060 \pm 90 \\
\delta^{13} C=-23.9 \%
\end{array}
$$

Charcoal, ref 5640G157, from hearth on old land surface, sealed by dump of upcast surrounding flint-mine shaft.

\section{BM-2379. Grime's Graves}

$$
4150 \pm 90
$$

Combined charcoal sample, ref 5640G121, 129, 129,124, 155, 105, 103 , from hearth sealed by dump of upcast surrounding flint-mine shaft.

\section{BM-2380. Grime's Graves}

$$
3810 \pm 60
$$
dump of up from antler, ref 5640G79, from old land surface sealed by dump of upcast surrounding flint-mine shaft, assoc with flint-knapping debris.

General Comment (FH): all three dates overlap with those obtained for antler picks abandoned during working of Greenwell's pit (R, 1979, v 21, p 4344). Dates indicate that activity in area of pit preceded its excavation by only short interval.

\section{Brixworth series}

Samples from All Saints' Church, Brixworth, Northamptonshire $\left(52^{\circ}\right.$ $20^{\prime} \mathrm{N}, 0^{\circ} 55^{\prime} \mathrm{W}$, Natl Grid Ref SP 745708). Subm by D Parsons, Univ Leicester.

\section{BM-2387. Brixworth}

$$
\begin{array}{r}
1370 \pm 60 \\
\delta^{13} C=-25.8 \%
\end{array}
$$

Charcoal, ref 600 , from immediately below mortar layer assoc with construction of church. Coll 1981.

\section{BM-2423. Brixworth}

$$
\begin{array}{r}
1560 \pm 60 \\
\delta^{l 3} C=-11.9 \% 0
\end{array}
$$

Mortar, ref MS $298(63 \mu \mathrm{m}$ fraction separated using Texas method, Folk \& Valastro, 1976) from surface rendering in vault in turret. Coll 1983.

General Comment (JA): BM-2423 is too early and must be contaminated with geol carbonate. Sample is part of research in ${ }^{14} \mathrm{C}$ dating of mortar to be pub elsewhere.

\section{Barrow Hills series}

Samples from series of deliberate deposits in fill of ditches of double ditched oval long barrow at Barrow Hills, Radley, Oxfordshire $\left(51^{\circ} 40^{\prime} \mathrm{N}\right.$, $1^{\circ} 15^{\prime} \mathrm{W}$, Natl Grid Ref SU 514984). Coll and subm 1984 by R Bradley, Dept Archaeol, Univ Reading. 


\section{BM-2390. Barrow Hills}

$$
\begin{array}{r}
4320 \pm 130 \\
\delta^{13} C=-20.6 \%
\end{array}
$$

Collagen from antler, ref 293, (red deer, base of tines) id. by Annie Grant, Univ Reading, from middle fill of outer ditch of barrow. Measured for terminus ante quem of initial fill of outer ditch and, indirectly, of primary burial assoc with polished knife and belt slider and for comparison with other similar deposits.

\section{BM-2391. Barrow Hills}

$4330 \pm 80$

Collagen from antler, ref 298, (red deer, base of antler with brow tine) id. by A Grant, from lowest fill of outer ditch. Measured for terminus ante quem of initial fill of outer ditch, primary burial, and comparison with material from other deposits in ditches.

\section{BM-2392. Barrow Hills}

$$
\begin{array}{r}
4500 \pm 60 \\
\delta^{13} C=-20.0^{\circ} \% 0
\end{array}
$$

Collagen from antler, ref 299, (red deer, fragment of beam and tines) id. by A Grant, from lowest fill of inner ditch. Measured for terminus ante quem of fill of ditch and, indirectly, of primary burial, and comparison with material from other deposits in ditches.

\section{BM-2393. Barrow Hills}

$4420 \pm 70$

$\delta^{13} C=-22.1 \%$

Collagen from antler, ref 302, (red deer, fragment of beam and base of tines) id. by A Grant, from middle fill of outer ditch of barrow in similar position to sample 293 (BM-2390) above. Measured for terminus ante quem of fill of ditch and, indirectly, of primary burial, and comparison with other deposits.

General Comment (RB): dates confirm this to be late long barrow, commencing construction during lifespan of nearby Abingdon causewayed enclosure.

\section{Wyke Down series}

Samples from single-entranced pit circle henge ( J Barrett, R Bradley \& $M$ Green, The prehistory of Cranborne Chase, $m s$ in preparation) at Wyke Down, Down Farm, Woodcutts, Dorset $\left(51^{\circ} 00^{\prime} \mathrm{N}, 2^{\circ} 00^{\prime} \mathrm{W}\right.$, Natl Grid Ref SU 006153). Coll and subm 1984 by R Bradley.

\section{BM-2394. Wyke Down}

$3460 \pm 90$

Collagen from bone, (fragment of right humerus of Bos sp) id. by A Grant, from Feature 1, Layer 3, lower fill of pit at center of henge, assoc with leaf-shaped arrowhead. Measured to check if pit is contemporary with rest of monument. 
BM-2395. Wyke Down

$4040 \pm 90$

$\delta^{13} \mathrm{C}=-22.5 \%$

Collagen from antler (red deer), id. by A Grant, from Pit 1, Layer 5, from silt in rapidly filled pit, 1 of 27 in pit circle aligned on Dorset Cursus. Measured to date monument and for comparison with dates from Maumbury Rings (BM-2281, -2282; R, 1986, v 29, no. 1, p 64).

\section{BM-2396. Wyke Down}

$4140 \pm 80$

Charcoal (Quercus sp, heartwood) id. by M Robinson, Univ Mus, Oxford, from secondary recut of pit belonging to pit circle henge.

\section{BM-2397. Wyke Down}

$4150 \pm 50$

Charcoal (Alnus, $>10$ yr old, Corylus, $>10$ yr old, Rhamnus, up to $25 \mathrm{yr}$ old, spp) id. by M Robinson from Tr K, Layer 3A, secondary recut in top of monument, apparently refilled immediately. Similar features on site contain Grooved Ware.

General Comment (RB): dates show site to be among earlier henge monuments in lowland Britain and some centuries earlier than superficially similar site at Maumbury Rings (BM-2281, -2282; R, 1987, v 29, no. 1, p 64). Wyke Down also provides some of earlier dates for Grooved Ware tradition in Wessex. BM-2394 shows central cremation to be secondary addition, most probably whilst nearby barrow cemetery was in use. Dates for Down Farm Neolithic Pits (see BM-2406, -2407, below) suggest that this settlement site, which was also assoc with Grooved Ware, was in use at same time as henge monument.

\section{Lindow Moss series}

Samples from peat close to preserved ancient male human body found in bog at Lindow Moss, Cheshire $\left(53^{\circ} 20^{\prime} \mathrm{N}, 2^{\circ} 10^{\prime} \mathrm{W}\right.$, Natl Grid Ref SJ 812808). Coll 1985 and subm by I Stead, Dept Prehist and Romano-British Antiquities, British Mus, as part of research into age of body and surrounding environment.

\section{BM-2398. Lindow Moss}

$2590 \pm 170$

$\delta^{13} C=-26.1 \%$

Humins, extracted from whole peat sample, ref 14, from column of weakly humified Sphagnum peat from underside of upper arm surface, close to skull.

\section{BM-2399. Lindow Moss}

$2470 \pm 250$ above.

Humic acids, extracted from same whole peat sample as BM-2398, 
BM-2400. Lindow Moss

$$
\delta^{13} C=-25.1 \%
$$

Humins, extracted from whole peat sample, ref 125, 16-19, from column of humified Eriophonum peat beside body.

\section{BM-2401. Lindow Moss}

$$
\begin{array}{r}
\mathbf{2 4 0 0} \pm \mathbf{1 0 0} \\
\delta^{13} C=-26.0 \%
\end{array}
$$

Humic acids, extracted from same whole peat sample as BM-2400, above.

General Comment ( JA \& SB): dates for humin and humic acid fraction from each peat sample agree well within counting error, indicating little mobility of humic acids within peat. Dates for 2 peat samples also agree well, as expected on strat grounds. Peat samples from above body (HAR-6562, $2290 \pm 90 \mathrm{BP}$ ) and from upper part of peat column 125 (HAR-6565, $2280 \pm 7(0 \mathrm{BP})$ give dates significantly later than BM dates using appropriate single-sided test, also as expected on strat grounds. Peat dates are earlier than dates for body produced by Oxford and Harwell labs. For full discussion of peat dates and details of dates for body, see Stead, Bourke \& Brothwell (1986).

\section{BM-2404. Stratford's Yard}

$$
\begin{array}{r}
\mathbf{5 8 9 0} \pm \mathbf{1 0 0} \\
\delta^{13} C=-22.5 \% 0
\end{array}
$$

Collagen from 5 bone fragments (Bos primigenius) id. by Caroline Grigson, from Stratford's Yard, Chesham, Buckinghamshire $\left(51^{\circ} 40^{\prime} \mathrm{N}, 0^{\circ}\right.$ $40^{\prime}$ W, Natl Grid Ref SP 960015) assoc with late Mesolithic flints. Coll 1969 by Bambi Stainton and subm by Caroline Grigson, Royal College of Surgeons, London, to provide date for assoc flint and to date Bos primigenius as part of late Pleistocene/early Holocene mammalian extinctions program (see, eg, R, 1983, v 25, p 39-41). Comment (CG): date confirms presence of Bos primigenius in S England in Atlantic period and id. of flint assemblage as Late Mesolithic.

\section{BM-2405. Wansdyke}

$1020 \pm 50$

$\delta^{13} C=-24.9 \%$

Charcoal sample consisting of many fragments (Quercus sp, at least partly from young wood) id. by Jacqui Watson, English Heritage, from ditch of Wansdyke, late Roman or post-Roman linear earthwork sectioned by oil pipeline trench at Wernham Farm, Savernake, Wiltshire $\left(51^{\circ} 25^{\prime} \mathrm{N}, 1^{\circ}\right.$ $45^{\prime}$ W, Natl Grid Ref SU 176668). Coll and subm 1985 by A J Clark on behalf of Trust for Wessex Archacol and Esso Petroleum Co. Comment (AJC): layer containing sample represented stable phase in silting of ditch, prior to fill with plough soil. Beneath lay mass of large loose flints $0.5 \mathrm{~m}$ deep, and late result indicates that these were probably derived from agric ground clearance after dyke had lost its significance, rather than from carly collapse of possible bank revetment.

\section{Down Farm Neolithic Pits series}

Samples from two clusters of late Neolithic pits (Barrett, Bradley \& Green, The prehistory of Cranborne Chase, $\mathrm{ms}$ in preparation) beside Dor- 
set Cursus, at Down Farm, Woodcutts, Dorset $\left(51^{\circ} 00^{\prime} \mathrm{N}, 2^{\circ} 00^{\prime} \mathrm{W}\right.$, Natl Grid Ref SU 000148). Coll 1977 and subm by R Bradley, Dept Archaeol, Univ Reading.

\section{BM-2406. Down Farm Neolithic Pits}

$4140 \pm 60$

Collagen from antler, ref $11 \mathrm{~A}$, (red deer, base of tine) id. by A Legre, Univ London, from upper fill of pit in one of clusters, assoc with Grooved Ware.

\section{BM-2407. Down Farm Neolithic Pits}

$$
4080 \pm 50
$$

Collagen from antler, ref 32 , (red deer, bas of ine) id. by A $24.2 \%$ from bottom of pit in different pit cluster to BM-2406, above a Legge, Grooved Ware and complex group of artifacts.

General Comment (RB): dates suggest that this site was in use at same time as nearby Wyke Down henge monument (BM-2394 to -2397, above).

\section{BM-2416. Down Farm}

$2450 \pm 110$

Collagen from bone, ref PH12 Ll (Bos sp, long bone) id. by A Legge, from fill of post hole of oval structure between pond barrow and Dorset Cursus at Down Farm, Woodcutts, Dorset $\left(51^{\circ} 00^{\prime} \mathrm{N}, 2^{\circ} 00^{\prime} \mathrm{W}\right.$, Natl Grid Ref SU 002137). Sample subm to determine terminus ante quem for structure and if structure is assoc with either pond barrow or cursus. Coll 1982 and subm by R Bradley. Comment (RB): date shows that this group of otherwise undated post holes is assoc with neither pond barrow nor cursus but relates to early Iron Age activity.

\section{Rollright series}

Samples from stone round cairn and ploughed-out round barrow near King Stone, single outlying monolith assoc with Rollright Stones megalithic complex, Great Rollright, $5 \mathrm{~km} \mathrm{~N}$ of Chipping Norton, Oxfordshire $\left(52^{\circ} 00^{\prime} \mathrm{N}, 1^{\circ} 30^{\prime} \mathrm{W}\right.$, Natl Grid Ref SP 296309). Coll 1982 and 1984 and subm by $\mathrm{G}$ Lambrick, Oxford Archaeol Unit.

\section{BM-2427. Rollright}

$3370 \pm 40$

Charcoal, ref RR VII 15/4, (mixed Quercus and Corylus spp) id. by Vanessa Straker, Univ Bristol, from cremation deposit secondary to construction of round cairn, next to King Stone, overlying first trace of collapsed cairn material and sealed by further collapse and rubble.

\section{BM-2428. Rollright}

$$
\mathbf{3 4 8 0} \pm \mathbf{5 0}
$$

Charcoal, ref RR VIII 17/4, (Corylus Oxford, from cremation deposit at base of id. by M Robinson, Univ Mus, Oxford, from cremation deposit at base of post hole in round barrow ca $40 \mathrm{~m}$ NW of King Stone. 
BM-2429. Rollright

$\delta^{13} C=-24.3 \%$

Charcoal, ref RR VIII 14, (Corylus sp) id. by M Robinson, from cremation deposit in pit in round barrow assoc with Collared Urn. Deposit was adjacent to that dated by BM-2428, above.

\section{BM-2430. Rollright}

$3490 \pm 70$

$\delta^{13} C=-23.0 \%$

Charcoal, ref RR VII 24, (Corylus sp) id. by V Straker, from scattered deposit, assoc with burned stones and burned human tooth from possible cremation, beside round cairn, sealed by rubble spill from collapse of cairn.

General Comment (GL): BM-2427 and -2430 relate to secondary cremation assoc with round cairn recently discovered immediately adjacent to King Stone monolith. On strat grounds both deposits largely antedate accumulation of stone flakes and rubble from weathering of cairn. Very few dates previously existed for round cairns in Cotswolds and even though these determinations do not date primary construction of cairn, they are valuable in providing good agreement for terminus ante quem. Since they underlie most of rubble accumulation they may suggest Beaker or Early Bronze Age date for cairn rather than earlier date. BM-2428 and -2429 are from outlying cremations within area of small unditched earthen round barrow ca $30 \mathrm{~m}$ from cairn. Strat relationships to barrow mound were destroyed by ploughing. BM-2429 is within later end of range expected for Collared Urns. BM-2428, from post-marked cremation is of interest in view of possible function of King Stone as cemetery marker. Separation of dates is slightly surprising because two deposits were immediately next to each other. Their proximity could be coincidental but may indicate longevity of marker dated by BM-2428.

\section{BM-2438. Dorset Cursus}

$$
\begin{array}{r}
4490 \pm \mathbf{6 0} \\
\delta^{13} C=-21.1 \% 0
\end{array}
$$

Collagen from antler, ref $3820 / 4$, (red deer) id. by A Legge, from partially stabilized surface on top of primary ditch silts and sealed by secondary silts containing Mortlake and Fengate Ware in ditch of Dorset Cursus (Barrett, Bradley \& Green, The prehistory of Cranborne Chase, $m$ in preparation) at Down Farm, Woodcutts, Dorset $\left(50^{\circ} 55^{\prime} \mathrm{N}, 2^{\circ} 00^{\prime} \mathrm{W}\right.$, Natl Grid Ref SU 007149). Coll 1984 and subm by R Bradley. Comment (RB): result is consistent with OxA-624 to -626 (Gowlett et al, 1986, p 122) indicating date towards end of early 5 th millennium BP for monument. Date also compares well with dates from long barrow at Wor Barrow (BM-2283, -2284; R, 1987 , v 29, no. 1, p 64). Being large antler pick, there is little chance that it had been moved around in soil profile during later activity and date can be regarded as more secure in context than samples subm to Oxford, which were much smaller. 


\section{BM-2432. Toome}

$1030 \pm 50$

Cellulose from wood (Quercus sp) from Toome, near Lough Neagh, Antrim, N Ireland $\left(54^{\circ} 45^{\prime} \mathrm{N}, 6^{\circ} 30^{\prime} \mathrm{W}\right)$ dendrochronologically dated to decade centered on AD 1015. Supplied by M Baillie, Queen's Univ, Belfast. Comment (JA \& SB): date, when calibrated with high-precision curve (Stuiver \& Pearson, 1986) gives date range of AD 965-1030, in good agreement with known age.

\section{Scotland}

\section{BM-2353. Synton Moss}

$\mathbf{5 3 6 0} \pm \mathbf{5 0}$

Collagen from left maxilla of Bos primigenius, from skeleton now in Roxburgh Mus, Hawick (accession nos. 1672-1676) found during excavation of drainage ditch, ca $0.9 \mathrm{~m}$ below present ground surface at junction of peat and shelly marl, at Synton Moss, Ashkirk Parish, Selkirkshire $\left(55^{\circ} 30^{\prime}\right.$ $\mathrm{N}, 2^{\circ} 50^{\prime} \mathrm{W}$, Natl Grid ref NT 485205). Coll 1980 by A Keddie and subm 1984 by J Rackham, Dept Archaeol, Univ Durham, to date apparently strat early Bos primigenius remains. Comment (JR): no archaeol assoc, but date and previous finds from Synton Moss indicate that fuller study of site is needed. Well-preserved adult female skeleton offers useful metric inf for sp.

\section{Cameroon}

\section{Mbi Crater series}

Samples from rock-shelter at Mbi Crater, near Bafanji $\left(6^{\circ} 05^{\prime} \mathrm{N}, 10^{\circ}\right.$ $20^{\prime}$ E). Coll 1982 and subm by R N Asombang, Inst Archacol, Univ London.

\section{BM-2425. Mbi Crater}

$$
\begin{array}{r}
4180 \pm 160 \\
\delta^{13} C=-24.9 \%
\end{array}
$$

Bulked charcoal, ref 12, from upper deposits of Sq 7C QM4, depth 45 to $50 \mathrm{~cm}$ from surface, assoc with lower levels of upper concentration of lithic material on site.

\section{BM-2426. Mbi Grater}

$$
\begin{array}{r}
2770 \pm 120 \\
\delta^{13} C=-26.1 \% 0
\end{array}
$$

Bulked charcoal, ref 9, from upper deposits in Sq 7C QM $1+3$, depth 15 to $20 \mathrm{~cm}$ from surface, assoc with lower levels of pottery on site.

General Comment (RNA): BM-2425 dates final late Stone Age leading to start of food production. BM-2426 indicates that food production was well established by beginning of 3rd millennium BP. Two dates are in correct 
stratigraphic order and compare well with other dates from region. Bone sample from lower levels of site is being dated by Oxford lab.

\section{Hungary}

\section{E Hungarian Neolithic series}

Samples dated to supplement series from Ko Békés and Ko HajdúBihar, E Hungary (R, 1983, v 25, p 48-50). Coll by froth flotation as part of Hungarian Acad Sci Topographic Prog and subm by J Chapman, Univ Newcastle upon Tyne.

\section{BM-2321. Tiszapolgár-Csöszhalom}

$$
\begin{array}{r}
6020 \pm 170 \\
\delta^{13} C=-24.4 \%
\end{array}
$$

Charcoal from late Neolithic layer, 80 to $110 \mathrm{~cm}$ deep, in tell at Tiszapolgár-Csöszhalom, Ko Hajdú-Bihar $\left(47^{\circ} 50^{\prime} \mathrm{N}, 21^{\circ} 20^{\prime} \mathrm{E}\right)$. Coll 1982. Comment (JC): result agrees reasonably well with previous dates for site (Bln509 to -513 ; R, 1970, v 12, p 412, and GrN-1993; R, 1963, v 5, p 184) obtained from excavation in 1959 to 1960 by I Bognár-Kutzian. Result is also consistent with two dates for late Neolithic Tisza culture from Kisköre (Bln-179, -515; R, 1970, v 12, p 409-410).

\section{Szegvár-Tüzkövés series}

Samples from late Neolithic Tisza deposits overlying middle Neolithic Szakalhát material in tell Szegvár-Túzkövés, $4 \mathrm{~m}$ high, Ko Békés $\left(46^{\circ} 40^{\prime} \mathrm{N}\right.$, $\left.20^{\circ} 10^{\prime} \mathrm{E}\right)$. Coll 1980 .

\section{BM-2322. Szegvár-Tüzkővés}

\section{BM-2323. Szegvár-Túzkóvés}

$6250 \pm 190$ $\delta^{13} C=-24.3 \%$

$$
6120 \pm 40
$$

$\delta^{13} C=-24.7 \% 0$

Charcoal from Pit 5, Tr 23.

General Comment (JC): samples came from pit of late Neolithic Tisza culture and are rather earlier than expected by comparison with dates from Kisköre (Bln-1 79, -515; R, 1970, v 12, p 409-410). This may be due to contamination from Szakalhát layers or use of old timbers, which would be unrecognizable from size of charcoal pieces.

\section{India}

\section{Zawar series}

Samples assoc with zinc mining over wide area at Zawar (Craddock et al, 1986), Udaipur Dist, Rajasthan $\left(23^{\circ} 20^{\prime} \mathrm{N}, 75^{\circ} 50^{\prime} \mathrm{E}\right)$. Coll 1983 and subm by P T Craddock, Research Lab, British Mus. 


\section{BM-2338. Zawar}

Wood from outer 5 rings of in situ support timber (Terminalia sp), id. by Paula Rudall, Royal Botanic Gardens, Kew, from W stope, first level in Balaria mine.

\section{BM-2381. Zawar}

Wood from outer 5 rings and bark of small branch (Terminalia sp), id. by $\mathrm{P}$ Rudall, from gallery in Mochia mine.

General Comment (PTC): BM-2338 is first date for material from inside mine to agree with dates previously obtained for zinc distillation installation on surface (BM-2222 to -2224; R, 1985, v 27, p 518-519). It is also significant that mine contains iron pyrites which is believed to have been used as flux for lead smelting at Zawar in recent times. BM-2381 shows that Mochia mine was in use during same period as mine at Zawar Mala (BM-2148, $-2149 ; \mathrm{R}, 1986, \mathrm{v} 26, \mathrm{p} 67-68)$.

\section{BM-2356. Agucha}

$$
\delta^{13} C=-24.4 \%
$$

Wood (Terminalia sp) id. by P Rudall, from mine prop, $30 \mathrm{~m}$ below ground, recovered in drill core from Agucha mine, Rajasthan $\left(25^{\circ} 50^{\prime} \mathrm{N}\right.$, $74^{\circ} 30^{\prime} \mathrm{E}$ ). Coll 1983 and subm by P T Craddock. Comment (PTC): site is close to remains of 3 rd century BC Mauryean settlement and is first major source of silver excavated in India. Date fits well with introduction of silver coinage to subcontinent.

\section{BM-2364. Ingaldahl}

$$
\begin{array}{r}
1810 \pm 35 \\
\delta^{13} C=-24.8 \%
\end{array}
$$

Wood from small branch found above 5 th level in Zone N11-N13, ca $40 \mathrm{~m}$ below surface in ancient copper mining workings at Ingaldhal mine, near Chitradurga, Karnataka (14 $\left.15^{\prime} \mathrm{N}, 76^{\circ} 25^{\prime} \mathrm{E}\right)$. Coll 1983 and subm by $\mathrm{R} F$ Tylecote for Chitradurga Copper Co as part of research into ancient mining in India. Comment (JA): date confirms early mining at site. For previous date from site, see PRL-252, $1680 \pm 100 \mathrm{BP} ; \mathrm{R}, 1978$, v 20, p 236.

\section{Israel}

\section{BM-2382. Timna}

Charcoal, ref 103 , from Site 2, Layer II, $50 \mathrm{~cm}$ inside slag heap at early smelting site in Timna Valley (Rothenberg, 1972; 1985), Wadi Arabah, Gulf of Aqaba (34 $55^{\prime} \mathrm{N}, 29^{\circ} 45^{\prime} \mathrm{E}$ ), assoc with circular tap slag. Coll 1982 and subm by B Rothenberg, Inst Archacol-Metallurgical Studies, London. Comment (BR): date completes additional studies in dating copper smelting furnaces of Site 2 at Timna. It is now evident that there was secondary occupation of this late Bronze Age copper smelting site in early Islamic period 
(see BM-2242; R, 1985, v 27, p 519). For other dates for Timna, see BM1115 to $-1117,-1162$, -1163; R, 1979, v 21, p 349-350: BM-1368, -1598; R, 1982, v 24, p 165.

Jordan

BM-2349. Dhuweila

$8190 \pm 60$

$\delta^{13} C=-12.1 \%$

Charcoal, ref BDS 2202311 , from layer of gray ash ca $1 \mathrm{~m}$ below surface, underlying structure and overlying bedrock in aceramic Neolithic hunting camp at Dhuwcila (Betts, 1985, p 33-34), E Jordan $\left(32^{\circ} 5^{\prime} \mathrm{N}\right.$, $37^{\circ} 15^{\prime} \mathrm{E}$ ) assoc with diagnostic flint implements. Coll 1983 and subm by Alison Betts, British Inst at Amman for Archaeol and Hist. Comment (AB): date fits well with sequence for area where PPNB seems to continue longer than in other places (Betts, 1986). Material from occupation layers at Wadi Jilat has produced dates of $8810 \pm 110 \mathrm{BP}, \mathrm{OxA}-526$, and $8520 \pm 110 \mathrm{BP}$, OxA-527 (Garrard, Byrd \& Betts, 1986) for strata with earlier tool kit than Dhuweila.

\section{Pakistan}

\section{BM-2402. Lak Largai}

$$
\begin{array}{r}
\mathbf{4 1 7 0} \pm \mathbf{5 0} \\
\delta^{13} C=-23.6 \%
\end{array}
$$

Charcoal sample, ref L.KL_l, from bottom of rubbish pit $(96$ to $108 \mathrm{~cm}$ below surface) in excavation near $\mathrm{N}$ edge of site at Lak Largai 1, Bannu Dist, NW Frontier Prov $\left(32^{\circ} 50^{\prime} \mathrm{N}, 70^{\circ} 30^{\prime} \mathrm{E}\right.$ ) assoc with 3rd millennium BP pottery. Coll 1985 and subm by K I) Thomas, Inst Archaeol, Univ London. Measured to date earlier Kot Dijian settlement in Bannu Dist and for comparison with dates from Rehman Dheri (BM-2062, -2063; R, 1983, v 25, p 52). Comment (KDT): date is, as expected, rather earlier than date for Islam Chawki (BM-2403, below) and compares well with early dates from Rehman Dheri (PRL-674 to -676 ; R, 1985, v 27, p 101), where similar (?) pre- and carly Kot Dijian pottery was found.

\section{BM-2403. Islam Chawki}

$3840 \pm 110$

$\delta^{13} C=-24.1 \%$

Charcoal, ref ISC1, from ashy material lying on floor deposit, $14 \mathrm{~cm}$ below surface, in small excavation on $\mathrm{W}$ edge of mound at Islam Chawki (Chauki), Bannu Dist, N W Frontier Prov (330 $\left.00^{\prime} \mathrm{N}, 70^{\circ} 30^{\prime} \mathrm{E}\right)$. Coll 1985 and subm by K D Thomas. Measured to date important Kot Dijian mound and Late Kot Dijian of region, and to compare with other date for site (BM$1941 ; \mathrm{R}, 1983, \mathrm{v} 25, \mathrm{p} 51$, pub under alternative transliteration of site name, Islam Chauki). Comment (KI)T): date is rather earlier than other date for site (BM-1941) but is in line with expected dates for Kot Dijian and with dates for nearby site of Tarakai Qila (BM-1690 to -1695; R, 1982, v 24, p 281). 
Poland

\section{Wierzbica series}

Charcoal from prehistoric flint mine at Zele, Wierzbica, Radom $\left(51^{\circ}\right.$ $15^{\prime} \mathrm{N}, 2^{\circ} 0^{\prime} \mathrm{E}$ ). Coll 1982 and 1983 by $\mathrm{H} \mathrm{M} /$ ynarczyk and J Lech and subm by J Lech, Inst Hist Material Culture, Polish Acad Sci, Warsaw.

\section{BM-2383. Wierzbica, Zele}

$3150 \pm 80$

Charcoal, ref combined samples 88 and $89 / 82$, from scattered fragments $(340 \mathrm{~cm}$ depth) in Cutting II/82 in fill of Shaft 20.

\section{BM-2384. Wierzbica, Zele}

$2550 \pm 280$

Charcoal, ref sample $110 / 82$, from scattered fragments $(420 \mathrm{~cm}$ depth) in Cutting II/82 in fill of Shaft 20.

\section{BM-2385. Wierzbica, Zele}

$2750 \pm 70$

$\delta^{13} C=-25.8 \%$

Charcoal, ref $183 / 83$, from scattered fragments (330 to $350 \mathrm{~cm}$ depth) in Cutting III/83 in fill of Shaft 28.

\section{BM-2385A. Wierzbica, Zele}

$2780 \pm 80$

Recount of BM-2385, above.

\section{BM-2386. Wierzbica, Zele}

Charcoal, ref $223 / 83$, from scatter of fragments in heap of large limestone blocks, assoc with traces of fire on limestone wall, near base of Shaft 28.

\section{BM-2386A. Wierzbica, Zele}

$$
2800 \pm 100
$$

Recount of BM-2386, above.

General Comment (JL): for other dates from site, see BM XVII; R, 1984, v 26, p 70, and Lech, 1984, p 194. Dates agree well with expected age for flint mining in this part of Zele (Lech, 1984). BM-2386 and -2386A are evidently contemporary with flint exploitation from Shaft 28 and late Bronze Age in Vistule basin. There are no dates for Neolithic and possible late Paleolithic mining on site for which there is independent archaeol evidence (Lech, 1983; 1984). BM-2386, -2386A are among latest dates for flint mining in central Europe (Lech, 1981). 
Spain

Early Metallurgy in S E Spain

Samples from Copper and Bronze Age sites in S E Spain, assoc with development of metal-working, subm by A Arribas, Univ Palma and F Molina, Univ Granada.

\section{Los Millares series}

Samples from carly Copper Age, "Los Millares" culture, occupation site containing evidence of metal-working at Los Millares, Santa Fe, Almeria $\left(37^{\circ} 00^{\prime} \mathrm{N}, 2^{\circ} 30^{\prime} \mathrm{W}\right)$. Coll 1983 by A Arribas and F Molina.

\section{BM-2343. Los Millares}

$4150 \pm 40$

Charcoal, ref LM-6015, from remains of wooden beam, embedded in one of reinforcements of Wall 2.

\section{BM-2344. Los Millares}

$4110+110$

Charcoal, ref LM-17042, from hut level contemporary with construction of barbican defending principal gate of Wall 1 .

\section{BM-2345. Los Millares}

$3820 \pm 40$

Charcoal, ref LM-62035, from central wooden beam supporting ceiling of bastion on outside of Fort 1 .

General Comments (AA): BM-2343 comes from Copper Age/Pre-Beaker phase and is as expected. BM-2344 belongs to phase immediately preceding appearance of Beaker material and is as expected. BM-2345 is from phase believed to be immediately pre-Beaker and is later than expected.

\section{El Malagon series}

Samples from early Copper Age, "Los Millares" culture, occupation site containing evidence of metal-working at El Malagon, Cúllar Baza, Granada $\left(37^{\circ} 30^{\prime} \mathrm{N}, 2^{\circ} 25^{\prime} \mathrm{W}\right)$. Coll 1983 by $\mathrm{F}$ Molina.

\section{BM-2347. El Malagon}

$4020 \pm 60$

Charcoal, ref CB-5130, from pit outside group of huts.

\section{BM-2348. El Malagon}

$3870 \pm 60$

Charcoal, ref CB-10213, from deposit outside hut.

General Comment (AA): dates are slightly later than expected.

\section{BM-2354. Terrera del Reloj}

Charcoal, ref DG.6094, from floor of hut in habitation layer of Bronze Age, "Argar Pleno" culture, site at Terrera del Reloj, Dehesas de Guadix, 
Granada $\left(37^{\circ} 35^{\prime} \mathrm{N}, 3^{\circ} 00^{\prime} \mathrm{W}\right)$. Coll 1983 by F Molina. Comment (AA): date is acceptable.

\section{Abrigo de la Peña series}

Samples from Abrigo de la Peña (Beguiristain \& Cava, 1984), rock shelter in gorge of R Ega, Marañón, Navarra $\left(42^{\circ} 40^{\prime} \mathrm{N}, 2^{\circ} 30^{\prime} \mathrm{W}\right)$. Coll 1983 and subm by I Barandiaran and A Cava, Univ Basque Country, Vitoria, and R J Harrison, Univ Bristol.

\section{BM-2357. Abrigo de la Peña \\ $2840+70$}

Charcoal, ref 1, from early Iron Age phase, Level b.

\section{BM-2358. Abrigo de la Peña}

$3610 \pm 60$

Charcoal, ref 2, from Bronze Age phase, Level b.

\section{BM-2359. Abrigo de la Peña}

$3710+60$

Charcoal, ref 3, from similar context to BM-2358, above.

\section{BM-2360. Abrigo de la Peña}

$4350 \pm 80$

Charcoal, ref 4, from carly Eneolithic phase, Level b.

\section{BM-2363. Abrigo de la Peña}

Collagen from bone (large herbivore, possibly Cervus) id. by I Barandiaran, ref 11, Level d, phase assoc with many flints, mostly small geometrics, of Epipalcolithic affinity.

General Comment (IB \& RJH): site was used for habitation and burial. Level b is thick stony accumulation up to $185 \mathrm{~cm}$ deep with many strat subdivisions within it. All dates are in correct strat order and coincide exactly with archaeol and ceramic materials assoc with them. This is best sequence for Basque region so far found.

\section{La Atalayuela series}

Collagen from human bone from mass grave of at least 70 individuals at La Atalayucla (Barandiaran \& Basabe, 1978), Agoncillo, La Rioja (42 $25^{\prime}$ $\mathrm{N}, 1^{\circ} 20^{\prime} \mathrm{E}$ ), assoc with Eneolithic grave goods, including at least 6 Bell Beakers of various styles, some very early. Beakers include pieces of CZM Beaker and sherds of Maritime transitional types with comb decoration. Coll 1970 by I Barandiaran, and subm 1983 by I Barandiaran and R J Harrison.

BM-2365. La Atalayuela

Collagen from human long bone, ref E2, from upper level of grave. 
BM-2366. La Atalayuela

$4120 \pm 70$

Collagen from human long bone, ref $\mathrm{E} 42$, from middle level of grave.

\section{BM-2367. La Atalayuela}

$4110 \pm 60$

Collagen from human long bone, ref E1 7, from middle or lower level of grave.

General Comment (IB \& RJH): grave was assumed to have been filled simultaneously since all skeletons were intact, flexed burials, and could be excavated individually. BM-2365, -2366 , and -2367 date bones from top, middle, and base of deposit, and are indistinguishable, showing tomb to be simultaneous burial. Dates for Bell Beakers are among oldest in W Europe and agree with other dates from Iberia.

\section{Berroberria series}

Collagen from bone samples from rock shelter used during Upper Paleolithic (Barandiaran, 1979), 100 to $120 \mathrm{~m}$ asl at Berroberria, Urdax, $\mathrm{N}$ frontier of Navarra $\left(43^{\circ} 15^{\prime} \mathrm{N}, 2^{\circ} 10^{\prime} \mathrm{E}\right)$. Coll 1979 by I Barandiaran and subm 1983 by I Barandiaran and R J Harrison.

\section{BM-2370. Berroberria}

$11,750 \pm 300$

Collagen from bone, ref 1 , from Level D, $\mathrm{Sq} 2 \mathrm{C}$, depth 235 to $250 \mathrm{~cm}$ assoc with final Magdalenian or Azilian flint industry, and fragment of "Azilian" harpoon.

\section{BM-2371. Berroberria}

$10,160 \pm 410$

Collagen from bone, ref 2 , from level I, similar context to BM-2370, above.

\section{BM-2373. Berroberria}

$13,270 \pm 220$

$\delta^{13} C=-20.5 \%$

Collagen from bone fragments, ref 4, from Level E, Sq 2G, depth 270 to $284 \mathrm{~cm}$, assoc with Upper Magdalenian flint industry.

\section{BM-2375. Berroberria}

$14,430 \pm 290$

Collagen from bone fragments, ref 6, from Level G, Sq 1G, depth 308 to $318 \mathrm{~cm}$, assoc with Middle Magdalenian flint industry.

General Comment (IB \& RJH): dates are in correct strat order and agree well with archaeol material assoc with them.

\section{Sri Lanka}

\section{Mantai series}

Samples from occupation at Mantai, on NW coast, $6.1 \mathrm{~km}$ SE of Mannar and $200 \mathrm{~m}$ from modern coast $\left(9^{\circ} 00^{\prime} \mathrm{N}, 80^{\circ} 00^{\prime} \mathrm{E}\right)$. Coll 1982 and subm by M E Prickett, Peabody Mus, Harvard Univ. 
BM-2340. Mantai

Charcoal, ref sample 1, from upper $40 \mathrm{~cm}$ of clay stratum.

$$
\delta^{13} C=-25.8 \%
$$

\section{BM-2341. Mantai}

$3550 \pm 70$

Charcoal, ref sample 2, from middle $15 \mathrm{~cm}$ of clay stratum.

\section{BM-2342. Mantai}

Charcoal, ref sample 3, from lowest $20 \mathrm{~cm}$ of clay stratum.

General Comment (MP): samples underlie Mesolithic midden deposit from hunter/gatherer camp on lagoon edge and date higher relative sea level ca $1 \mathrm{~m}$ above modern. Dates correspond well with other evidence in Sri Lanka for late continuation of Stone Age occupation and for higher sea levels.

\section{United Arab Emirates}

\section{Ghanadha series}

Samples from multi-period site at Ghanadha Island (al-Tikriti, 1985), Abu Dhabi ( $\left(25^{\circ} 00^{\prime} \mathrm{N}, 54^{\circ} 40^{\prime} \mathrm{E}\right)$. Coll 1982 and subm by Walid al-Tikriti, Dept Antiquities, Abu Dhabi.

\section{BM-2261. Ghanadha 2}

Charcoal, ref sample 3, from fireplace no.1, $40 \mathrm{~cm}$ below surface of Site 2, S of Umm an-Nar Site 1.

\section{BM-2263. Ghanadha 3}

$3010 \pm 220$

Charcoal, ref sample 1, from inside Structure $1,10 \mathrm{~cm}$ below surface, assoc with Iron Age pottery.

General Comment (Wa-T): BM-2261 is later than date originally suggested for site, but lack of assoc material together with nature of Iron sites in UAE makes estimation difficult. BM-2261 indicates that fireplace belongs to final stages of occupation of site, which is believed to end in mid-1 st century BC. BM-2263 is slightly earlier than expected but problem of dating Iron Age in Gulf will not be solved until there is series of reliable dates for sevcral sites in area. Both dates are acceptable within present state of knowledge.

\section{REFERFNCES}

al-Tikriti, Walid Yasin, 1985, The archaeological investigations on Ghanadha Island 19821984: Further evidence for the coastal Umm an-Nar culture: Archaeol United Arab Emirates, $v 4, \mathrm{p} 9-19$

Ambers, J, Leese, $\mathrm{M}$ and Bowman, S, 1986, Detection of bias in the background of vials used for scintillation counting in Stuiver, $\mathrm{M}$ and $\mathrm{Kra}, \mathrm{R} \mathrm{S}$, eds, Internal ${ }^{19} \mathrm{C}$ conf, 12 th, Proc: Radiocarbon, v 28, no. 2A, p 586-591.

Balch, H E, 1927, Chelm's Combe Shelter: Somerset Archaeol Nat Hist Soc Proc, v 72, p 97 123.

Barandiaran, I, 1979, Excavaciones en el covacho de Berroberria (Urdax): Trabajos Arqueol Navarra, v 1, p $11-60$. 
Barandiaran, I and Basabe, J, 1978, El yacimiento Eneolithico de La Atalayuela en Agoncillo (Logrono): Principe Viana, no. 152-153, p 381-478.

Beguiristain, M A and Cava, A, 1984, Exploraciones en el Abrigo de La Peña (Marañón, Navarra): Trabajos Arqueol Navarra, v 4, p 7-18

Betts, A, 1985, Black Desert survey, Jordan: Third prelim rept: Levant, v 17, p $29-52$. (ms), 1986, The prehistory of the Basalt Desert, Transjordan: an analysis: PhD dissert, Univ London.

Burleigh, R, Currant, A, Jacobi, E and Jacobi, R, in press, A note on some British late Pleistocene remains of horse (Equus ferus), in Uerpmann, H-P and Meadow, R H, eds, Bcih zum Tübinger Atlas des Vorderen Orients: Wiesbaden, Reihe A, in press.

Clutton-Brock, J and Burleigh, R, 1981, Some archacological applications of the dating of animal bone by radiocarbon with particular reference to post-Pleistocene extinctions, in Internatl Symposium on C-1 4 and Archacol, 1 st, Proc, Groningen, Netherlands: PACT, v $8, \mathrm{p} 409-419$.

__ _ in press, The skull of a Neolithic horse from Grime's Graves, Norfolk, England, in Uerpmann, H-P and Meadow, R H, eds, Beih zum Tübinger Atlas des Vorderen Orients: Wiesbaden, Reihe A, in press.

___ _ _ in press, The mandible of a Mesolithic horse from Seamer Carr, Yorkshire, England, in Uerpmann, H-P and Meadow, R H, eds, Beih zum Tübinger Atlas des Vorderen Orients: Wiesbaden, Reihe A, in press.

Craddock, P T, Freestone, I C, Gurjar, L. K, Hegde, K T M and Sonawane, V H, 1986, Early zinc production in India: Mining Mag, Jan vol, p 45-52.

Drew, C I, and Piggott, S, 1936, The excavation of long barrow 163a on Thickthorn Down, Dorset: Prehist Soc Proc, v 2, p 77-96.

Evans, J G and Simpson, I) I) A, 1986, Radiocarbon dates for the Giants' Hills 2 Long Barrow, Skendleby, Lincolnshire, in Gowlett, J A J and Hedges, R E M, eds, Archacological results from accelerator dating: Oxford Univ Comm Archaeol mon ser, Oxford.

Folk, R L and Valastro, S, 1976, Successful techniques for the dating of lime mortar by carbon-14: Jour Field Archaeol, v 3, p 203-208.

Garrard, A N, Byrd, B and Betts, A, 1986, Prehistoric environment and settlement in the Azraq Basin: an interim report on the 1984 excavation season: Levant, v 18, p 5-21.

Gillespie, R, Gowlett, J A J, Hall, E T, Hedges, R F. M and Perry, C, 1985, Radiocarbon dates from Oxford AMS system: Archacometry datelist 2: Archacometry, v 27, p 236-246.

Gowlett, J A J, Hall, E T, Hedges, R E M and Perry, C, 1986, Radiocarbon dates from Oxford AMS system: Archacometry datelist 3: Archaeometry, v 28, p $116-125$.

Harrison, D L, Clutton-Brock, J, and Burleigh, R, 1981, Remains of mammals from the Darent river gravels at Sevenoaks Reserve, Kent: Archaeol Cantiana, v 97, p 27-52, pls I-V.

Lech, J, 1981, Flint mining among the early farming communities of Central Europe: Przeglad Archaeol, v 28, p 5-55.

___ _ 1983, Flint mining among the early farming communities of Central Europe, Part II, The basis of research into flint workshops: Przeglad Archaeol, v 30, p 47-80. 1984, The prehistoric flint mine at Wierzbica "Zele": a case study from Poland: World Archaeol, v 16, p 186-203.

Rothenberg, B, 1972, Timna-valley of the Biblical copper mines: London, Thames and Hudson.

1985, Copper smelting furnaces in the Arabah, Isracl; the archacological evidence, in Craddock, $\mathrm{P}$ T and Hughes, $\mathrm{M}$ J, eds, Furnaces and smelting technology in antiquity: British Mus Occ paper 48, p 123-150.

Stead, I M, Bourke, J B, and Brothwell, D, eds, 1986, Lindow Man: the body in the bog: London, British Mus Pubs.

Stuiver, M and Pearson, G W, 1986, High precision calibration of the radiocarbon time scale, AD 1950-500 BC, in Stuiver, $M$ and Kra, R S, eds, Internat ${ }^{14} \mathrm{C}$ conf, 12 th, Proc: Radiocarbon, $v 28$, no. $2 \mathrm{~B}, \mathrm{p} 805-838$.

Stuiver, $\mathrm{M}$ and Polach, H, 1977, Discussion: Reporting of ${ }^{14} \mathrm{C}$ data: Radiocarbon, v 19, no. 3, p $355-363$.

Wilkinson, T J, 1983, The Hullbridge Basin Survey Interim Report No. 4: Essex Co Council. 